\title{
Solidarity in diverse societies: beyond neoliberal multiculturalism and welfare chauvinism
}

Will Kymlicka

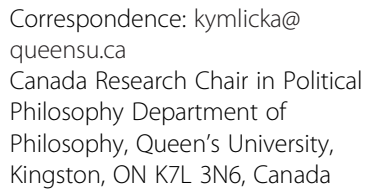

Correspondence: kymlicka@ queensu.ca

Canada Research Chair in Political Philosophy Department of Philosophy, Queen's University, Kingston, ON K7L 3N6, Canada

\begin{abstract}
In the postwar period, projects of social justice have often drawn upon ideas of national solidarity, calling upon shared national identities to mobilize support for the welfare state. Several commentators have argued that increasing immigration, and the multiculturalism policies it often gives rise to, weaken this sense of national solidarity. This creates a potential "progressive's dilemma", forcing a choice between solidarity and diversity. My aim in this paper is two-fold: first, to argue for the importance of national solidarity as a progressive political resource; and second, to discuss how it can be reconciled with support for immigration and multiculturalism. I will try to identify the prospects for a multicultural national solidarity - a multicultural welfare state, if you will - and to contrast it with the two obvious alternatives: a neoliberal multiculturalism that champions mobility and diversity at the expense of national solidarity; and a welfare chauvinism that champions national solidarity at the expense of immigrants and minorities.
\end{abstract}

Keywords: Solidarity, Immigration, Multiculturalism, Neoliberalism, Welfare state

For almost twenty years, the left has debated what is sometimes called the new progressive's dilemma: the fear that there is a trade-off between being pro-immigrant and being pro-welfare state. Large-scale immigration, and the ethnocultural diversity it brings with it, may make it more difficult to build or sustain the feelings of shared belonging and solidarity needed to maintain a robust welfare state. Extending justice to newcomers may weaken justice for the less-well-off members of the native-born working class.

Attempts to empirically measure the existence of such a trade-off have produced mixed and inconclusive results, ${ }^{1}$ and many commentators dismiss the idea that there is an inherent or inexorable universal tendency for ethnic or religious heterogeneity to reduce solidarity. After all, the very categories of "immigrant", "foreigner" and "ethnic diversity" are not brute facts, but are socially constructed. This is reflected in the many different ways that researchers define the "others" who are said to challenge existing bonds of nationhood: some researchers only look at those immigrants who have not naturalized, others include anyone who was foreign-born regardless of their legal status; some look only at the first generation foreign-born population, others assume that the native-born second generation also count; some researchers include immigrants from all foreign countries, others only count people from outside the $\mathrm{EU}$, on the 
assumption that fellow Europeans are not really "others"; and so on. For the purposes of testing whether ethnocultural diversity erodes a feeling of national belonging, should a child of Irish immigrants who is born in London be counted amongst the national "we" that is being challenged by immigration, or amongst the immigrant "they" who pose the challenge? Any answer to the question seems arbitrary at best, and meaningless at worst.

Once we recognize the contingency of perceptions of commonality and otherness, it might seem that the very idea of a progressive's dilemma relating to immigration is unhelpful or misguided. There is no reason to assume in advance that immigrants form a "they", or indeed that the native-born form a "we": the lines of identification are likely to be infinitely more complex and variable. To assume otherwise is to commit the sin of methodological nationalism: ie., to naturalize and reify the nation-state, to exaggerate its internal cohesion, and to assume that it defines the natural boundaries of politics, society and culture. Much of the existing literature on the progressive's dilemma does indeed suffer from this sort of methodological nationalism, and thereby implicitly and uncritically "mirrors and legitimizes nation-building projects" (Sager, 2014).

Nonetheless, I think the progressive's dilemma cannot be dismissed so easily, in part because nation-building projects - with their social constructions of a national 'we' and a foreign 'they' - are pervasive features of the contemporary world. Moreover, I believe these projects are sometimes legitimate, not just in the sense that they comply with minimal standards of democratic legitimacy and constitutional rights, but in the deeper sense that they are justice-promoting. Nation-building projects can be, and often have been, progressive political projects, mobilizing national solidarity against class privilege.

One of the ironies of the ubiquity of methodological nationalism is that it has discouraged investigation into the actual political functions of nationhood. Insofar as nationhood is the "invisible background" for much of social science and political theory (Sager, 2014), inadequate attention has been paid to the diversity of roles and functions that nationhood actually plays in our social and political lives. Margaret Canovan (1996) suggests we should view nationhood as a battery that energizes much of politics, and like all batteries, it can be highly charged or more or less depleted, and it can be used to power diverse projects, progressive and regressive. Scholars of migration are typically conscious of one particular function of nationhood: namely, when it is a highly charged battery used for the regressive purpose of excluding immigrants. But a fuller analysis would reveal that nationhood can also serve as an effective battery for many social justice claims.

And if so, then the progressive's dilemma returns, not because immigration is an abnormal contamination of naturalized nationhood, but because the progressive project of defending immigration and multiculturalism may push in different directions than the progressive project of defending national solidarity. Neither is more or less natural: they are both projects for making the world more decent and humane. And the challenge then is to think about how to reconcile them, and how to minimize any negative effects each might have on the other.

So my aim in this paper is two-fold: first, to argue for the importance of national solidarity as a progressive political resource; and second, to discuss how it can be reconciled with support for immigration and multiculturalism. I will try to identify the 
prospects for a multicultural national solidarity - a multicultural welfare state, if you will - and to contrast it with the two obvious alternatives: a neoliberal multiculturalism that champions mobility and diversity at the expense of national solidarity; and a welfare chauvinism that champions national solidarity at the expense of immigrants and minorities.

\section{Nationhood}

Why might nationhood be progressive? Several political theorists have offered normative justifications for the political project of nationhood, and I won't attempt to repeat all of the arguments here. ${ }^{2}$ So let me start with the simplest one - namely, the role of nationhood in stabilizing the demos, the units of democratic governance. Some political philosophers have implied that stability is assured simply by having a consensus on the principle of democracy itself: if everyone agrees on the principle that decisions should be made democratically, then democratic procedures will be stable. But a shared consensus on democracy tells us nothing yet about the units within which decisions will be made. Imagine that everyone on the continent of Europe shares a commitment to democracy. That doesn't yet tell us whether there should be one state in Europe, or twentyeight, or two hundred and eighty. Nor does it tell us how the boundaries of these units should be drawn: should they be drawn as straight grid lines of latitude and longitude, or should they follow topography or historical settlement patterns? We cannot act upon our shared democratic principles until we have at least a provisional consensus on the number and borders of political units.

And yet nothing whatsoever in democratic theory entitles us to the assumption that such a provisional consensus will emerge. On the contrary, democratic theory, on its own, should lead us to the opposite expectation. After all, it's the first premise of all democratic theory that people diverge in their preferences. People differ in their interests, their identities, their religious beliefs, and we need democracy precisely to reach decisions in the face of these "facts of pluralism". ${ }^{3}$ Yet all of these reasons for expecting people to have diverging preferences about policy are also, prima facie, reasons for expecting people to have diverging preferences about the units of democracy. In order to get democracy off the ground, we need to somehow combine diverging preferences about policy with converging preferences about units.

This peculiar combination of diverging policy preferences and converging unit preferences is the structural presupposition of democracy, but to repeat, nothing in democratic theory entitles us to expect such a combination. So what does explain it? To date, the answer is typically nationhood. Nationhood provides a sense of belonging together and a desire to act collectively. Ideas of belonging together, collective agency and attachment to territory are part of the very meaning of shared nationhood. Where a sense of nationhood is widely diffused, people think it is right and proper that they form a single unit, and that they should act collectively, despite their diverging interests and ideologies. ${ }^{4}$ Nationhood, in short, generates converging preferences on units.

Nationhood may also help facilitate the sort of solidarity required for a redistributive welfare state. To be sure, a sense of shared nationhood is not required for us to show a humanitarian concern for the suffering of others. Humans as a species are not psychopaths, indifferent to the suffering of others. We can be moved to provide aid in response to famines in distant societies, or to provide emergency health care for tourists 
who fall ill, without requiring that the recipients be "one of us". We can recognize duties of rescue to the needy, or duties of hospitality to the stranger, and some people are even moved to protect members of other species who are suffering or in distress, or who need protection from harm. These are all humanitarian responses to needs that do not depend on any sense of nationally-bounded solidarity.

But the welfare state is not about a humanitarian impulse to relieve suffering, offer hospitality, or rescue from distress. The welfare state, at least in the robust form endorsed by progressives, is rooted in an ethic of social membership. As the term implies, social justice is about the mutual concern and obligation we have as members of a shared society, and rest on some image of a decent, good or just society and of the sort of egalitarian relations that should characterize it. Social justice involves an ongoing commitment to create and uphold just institutions, ${ }^{5}$ including (for example) the social policies that help people avoid getting sick in the first place. If someone has a heart attack in front of us on the street, we have a humanitarian obligation to assist, whether they are tourists or citizens, but in the case of citizens, we also have an obligation to identify and address factors (such as economic insecurity) that make some people much more vulnerable to heart attacks than others. We typically do not think we have a comparable obligation with respect to tourists. We might say that justice amongst members is egalitarian, whereas justice to strangers is humanitarian, and social justice in this sense arguably depends on bounded solidarities. ${ }^{6}$ Nationhood has helped to secure such an ethic of membership, and its resulting bounded solidarity. ${ }^{7}$

This claim that the welfare state depends on national solidarity is controversial. There are alternative explanations for the emergence and maintenance of welfare states that emphasize the role of self-interest, strategic action, contestation and conflict rather than feelings of solidarity. A prominent approach to explaining the historical development of welfare states has been "power resource theory", which associates a strong welfare state with the relative strength of left political coalitions, incorporating strong labour movements and successful left political parties, particularly social democratic parties (Korpi, 1983; Esping-Andersen 1985, 1990; Stephens, 1979). On this view, the size and shape of welfare states is determined by the balance of power between those who have a self-interest in expanding the welfare state and those who have a selfinterest in reducing it. The outcome of this bargaining game may be a stronger welfare state if trade unions and social democratic parties are particularly powerful and/or able to form strategic coalitions with other popular forces. But this need not require or entail that anyone acts out of national solidarity.

Indeed this was how the left itself once understood the struggle for the welfare state. Socialist parties initially understood themselves as class parties engaged in class struggle, drawing upon class solidarity to defeat their class enemies. But the breakthrough for social democracy occurred when they abandoned this self-conception, and redescribed themselves as a "people's party" representing the nation as a whole and appealing to solidarity amongst co-nationals as a basis for social justice. As Sheri Berman notes, this transition from class solidarity to national solidarity was bitterly contested on the left in many European countries, in part due to the lingering influence of Marxism and its doctrine that all history is the history of class struggle (Berman, 2006). But the idea of the welfare state as an expression of an ethic of nationhood - captured so evocatively in Per Albin Hansson's idea of a "people's home" (folkhemmet), or in T.H. Marshall's 
claim that the welfare state rests on "a direct sense of community membership based on loyalty to a civilisation that is a common possession" (Marshall 1963: 96) - proved to be politically more effective. $^{8}$

Note again how the welfare state here is tied to an image of social membership, not universal humanitarianism. The assumption, for both the Swedish Social Democrats and the British Labour party, is that we form a community, and that the function of the welfare state is to ensure that everyone feels equally at home in the community, that everyone can equally partake in the cultural life of the community and enjoy its civilization, and that everyone can feel that they belong to the community and that the community belongs to them. It is this vision of the welfare state as an expression of national solidarity - and not just of class struggle or of universal humanitarianism - that powerfully inspired social democratic politics. ${ }^{9}$

It remains true that the shape and size of the welfare state depends in part on the balance of class forces. But the mobilization of national solidarity, alongside class bargaining, also matters. This suggests that the linkages between strategic and solidaristic accounts are complex and multi-layered. Successful efforts to create more redistributive welfare states are always contested, not the spontaneous result of pre-existing feelings of enhanced solidarity, and so depend on the contingent balance of power. But one of the resources wielded by progressive actors in that contest is appeals to national solidarity. Moreover, these reforms can over time reinforce feelings of national solidarity, which help to secure the reforms against the vagaries of power politics, as they become seen as common possessions or achievements of the nation, and not just the spoils of partisan battles. After all, the power of trade unions and social democratic parties has weakened at various times and places, yet welfare states have largely endured, arguably because they helped to build the very feelings of national solidarity needed to sustain them. ${ }^{10}$

So we have at least two strong reasons why nationhood can be seen as a progressive political project: it can operate to stabilize democracy and to build and sustain redistributive welfare states. A fuller discussion might examine other progressive rationales for nationhood, including the importance of a shared national language for democratic participation and equality of opportunity, or the role of nationhood in motivating concern for future generations (understood as the nation's future) and the environment (understood as the nation's homeland and patrimony). There are multiple factors that help to explain the "elective affinity" between nationhood and liberal democracy (Canovan, 1996).

However, as we all know, this link between nationhood and liberal-democracy creates endemic risks for all those who are not seen as belonging to the nation, including indigenous peoples, substate national groups and immigrants. Since they are not seen as members of the nation or people in whose name the state governs, and may indeed be seen as potentially disloyal fifth columns, they are often not trusted to govern themselves or to share in the governing of the larger society. And this exclusion is typically then buttressed and justified by ideologies of racial inferiority or cultural backwardness. In short, while liberal-democracy has benefitted in important ways from its link with nationhood, minorities have often paid a high price. They have been faced with social stigmatization and racialization, at best offered a stark choice of assimilation or exclusion, and at worst subject to expulsion or genocide. 
This is why, in my view, any legitimate form of liberal nationalism must be supplemented and constrained by multiculturalism (Kymlicka, 2001). Multiculturalism aims to mitigate the costs to minorities of the elective affinity between liberal democracy and nationhood. If liberal democracy had not entered the world tied to ideas of nationhood, it is possible that we would not need multiculturalism, at least not in the form we know in the West. But in our historical situation, some remedy was required for the unjust and exclusionary consequences of the privileging of nationhood and its associated ideologies.

And this raises the progressive's dilemma. We need multiculturalism to make liberal nationalism legitimate, but multiculturalist reforms may weaken the bonds of nationhood and hence its ability to secure stability and solidarity. I should emphasize that I am not claiming - as some of my liberal nationalist colleagues do - that nationhood is the only possible basis for achieving progressive ends, or that there are no alternative ways of generating converging preferences on political units, or generating a solidaristic ethics of social membership. I welcome attempts to develop alternative accounts of political order that seek to avoid reliance on nationhood, including various post-national cosmopolitan, agonistic, or ecological theories of democracy and citizenship. One of the central tasks of political theory is to imagine other worlds - to theorize possible alternatives to nationhood as the basis for democracy and redistribution. Political theory should open up our political imagination, not close it down.

However, one test of the adequacy of any such alternative is that it gives some account of what generates converging preferences about the unit of decision-making in the absence of nationhood. And in my view, the existing alternatives available in the literature fail this test. Theorists clearly assume such converging preferences, but offer no explanation for them. And if we scratch the surface, it becomes clear that they typically smuggle back in the very assumptions of nationhood that they purport to reject. I think this is true, for example, of Habermas's (2000) and Benhabib's (2006) accounts of postnational democracy, or Connolly's (2000) account of rhizomatic democracy. And having underestimated the extent to which their own theories rely on nationhood, they also systematically underestimate the need to supplement and constrain nationhood by multiculturalism.

So the construction of post-national alternatives to liberal nationalism remains an important task for future work. But in the meantime, for the foreseeable future at least, we live in a world where nationhood serves important political functions. And this inevitably leads to the question of how multicultural diversity affects these functional roles. In particular, does multiculturalism erode national solidarity, as the progressive dilemma asserts? ${ }^{11}$

\section{Beyond Neoliberal Multiculturalism and Welfare Chauvinism}

It is worth pausing to consider why this worry has become so prominent in recent years. Part of the explanation, I believe, is that the rise of multiculturalism in many countries in the 1980s and early 1990s coincided with the rise of neoliberalism and the restructuring of the welfare state. Moreover, the same international organizations that championed neoliberalism in the 1980s - such as the World Bank, the OECD or the $\mathrm{EU}^{12}$ - also pushed multiculturalism. As a result, in at least some countries, citizens experienced the rise of multiculturalism as part and parcel of an (imposed) neoliberal 
package: they were told to better respect migrants and minorities at the same time they were told to gut their social protection schemes. Or put another way, they were told to extend equality to minorities, but the meaning of "equality" was being reduced and reinterpreted in a neoliberal form, as essentially equal access to (or perhaps better, equal exposure to) the competitive global marketplace. The result has been aptly described as a form of "neoliberal multiculturalism" (or "Benetton multiculturalism"): the equal right of all to market themselves and their culture, and to safely consume the cultural products of others, indifferent to issues of disadvantage. In short, inclusion without solidarity.

Indeed, some commentators assume that this is the original and essential form of multiculturalism. Perhaps the best-known version of this argument is from Slavoj Žižek, who famously stated that multiculturalism emerged as the "cultural logic of multinational capitalism" (Žižek, 1997). Similar arguments have been made by other commentators, whether in relation to immigrants (Mitchell, 2004), national minorities (Cardinal \& Denault, 2007) or indigenous peoples (Hale, 2005). In each case, the central argument is that multiculturalism emerged as a technique of neoliberal governance, as a way of integrating minorities and minority cultural products into global markets.

I have elsewhere argued that this story is demonstrably wrong as an account of the genealogy of multiculturalism (Kymlicka, 2013). Multiculturalism arose in the 1960s, well before the era of neoliberalism, and was rooted in a social democratic impulse, defended as a natural extension of civil rights struggles and citizenship struggles. Moreover, the initial reaction of Thatcherite and Reaganite neoliberals was to reject multiculturalism, precisely because it was seen as a project of the social democratic ("nanny") welfare state. And in some countries, neoliberals never relinquished this original hostility to multiculturalism.

But for a variety of complex reasons, neoliberals in some countries - and in some international organizations - eventually decided they could work with multiculturalism, transforming it in a neoliberal direction, reframing it as a project of market inclusion rather than citizenship. Multiculturalism, as reimagined by neoliberals, was not about redressing the social and political marginalization of minorities generated by the privileging of nationhood. Rather, it was about enabling minorities to use their cultural markers as a source of market inclusion, either directly through commodifying cultural products (dress, music, food etc.), or indirectly by exploiting (transnational) ethnic networks as sources of social capital. And it was about persuading majorities to feel comfortable and competent when interacting with minorities in the workplace and marketplace, including the migrant workers desired by employers (Menz, 2013). It was this neoliberal version of multiculturalism - ethnicity, mobility and intercultural competence as market assets - that was promoted actively in the 1980s and early 1990s, and that in some places eclipsed the earlier more emancipatory vision of multiculturalism. ${ }^{13}$

As a result, many citizens experienced multiculturalism and neoliberalism as a single phenomenon, as two sides of the same coin that threatened inherited schemes of national solidarity. And understandably, many citizens recoiled from this image of neoliberal multiculturalism, and mobilized to defend national solidarity and the welfare state. But all too often, this mobilization has taken the inverse form of neoliberal multiculturalism: that is to say, welfare chauvinism, or solidarity without inclusion. Social 
protection is reserved for those who fit some narrow definition of national belonging. Immigrants' access to the welfare state is not only delayed or deferred for varying periods of time, but a range of new obstacles are put in place that make it difficult or unpredictable to meet these thresholds for access. Proposals for this sort of welfare chauvinism were initially formulated by far-right anti-immigrant populist parties, but have become distressingly popular across the political spectrum, and indeed implemented as public policy, as mainstream parties of both the right and centre seek to avoid bleeding votes to the populist right. ${ }^{14}$

At times, then, we seem confronted with a stark choice between neoliberal multiculturalism - inclusion without solidarity - and welfare chauvinism - solidarity without inclusion. As stated earlier, my preference is for a third option: inclusive solidarity through a multicultural welfare state. ${ }^{15}$ But is this a realistic possibility? It may sound attractive philosophically, but is it politically viable, or do we face a hard trade-off between national solidarity and multiculturalism? As Paul Collier notes, "most people who consider themselves progressive want multiculturalism combined with rapid migration and generous social welfare programs", but he argues that "some combinations of policy choices may be unsustainable", and he claims that multiculturalism and national solidarity are such an unsustainable combination (Collier, 2013: 264-5).

Is it sustainable, and if so, what would be the sources or preconditions of such an inclusive solidarity? This is a key question, but unfortunately we have little surprisingly little research on it. ${ }^{16}$ Neither the welfare state literature nor the multiculturalism literature has attended in any depth to the role of solidarity, either as a precondition or an outcome. Relatively little has been written about the extent to which the welfare state or multiculturalism presuppose solidarity, create solidarity, or erode solidarity. This partly reflects the dominance of the power resources theory within the welfare state field, but it is also reflects the fact that the very concept of "solidarity" has been neglected in social sciences and political theory. Several commentators have noted the "curious absence" (Reynolds, 2014) and "surprising gap" (Scholz, 2008) of solidarity as a subject of research in sociology (Reynolds, 2014: 1; Alexander, 2014), political science (Stjernø, 2004: 20) or in moral and political philosophy (Bayertz, 1998: 293; Scholz, 2008: 10). Wilde speculates that this is because solidarity is seen as "confined to the realm of rhetoric" - as a rhetorical trope of politicians - and not something fit for serious theoretical work (Wilde, 2007: 171) ${ }^{17}$ Alexander speculates that solidarity is ignored because it does not fit well with "influential theories of modern society":

Solidarity is a central dimension of social order and social conflict, yet it has largely been absent from influential theories of modern society. Most of the big thinkers, classical, modern and contemporary, have conceived prototypically modern relationships as either vertical or atomized. Modernization is thought to have smashed affectual and moral fellow-feeling: because of commodification and capitalist hierarchy (Marx), because of bureaucracy and individualistic asceticism (Weber), because of the growing abstraction and impersonality of the collective consciousness allows egoism and anomie (Durkheim). Postmodernity is typically seen as liquefying social ties and intensifying narcissistic individualism (Baumann); or as creating new forms of verticality, for example, the disciplinary cage (Foucault). (Alexander, 2014: 
In short, "much of contemporary social theory has tried to make solidarity disappear". Yet I agree with Alexander that solidarity "remains a central dimension of cultural, institutional and interactional life in contemporary societies" (Alexander, 2014: 304). For justice to be possible, "citizens need to be motivated by solidarity, not merely included by law" (Calhoun, 2002: 153).

Given the meagre literature, my discussion of the sources of inclusive solidarity will inevitably be partial and speculative, and intended primarily to spur more and better research. But we can start with some good news. Despite the pessimistic claims of some of the earliest proponents of the progressive's dilemma, it is now clear that there is no inherent or universal tendency for multiculturalism to drive down solidarity. Crossnational studies show that countries which have gone farther down the road of embracing multiculturalism policies have on average fared as well as other countries in maintaining social spending, in maintaining public support for redistributive programs, and in maintaining attitudes of inclusive solidarity (Banting \& Kymlicka, 2006, (in press;) Brady \& Finnigan 2014; Kesler \& Bloemraad 2010; Crepaz 2006; Guimond et al. 2013). While multiculturalism and neoliberalism may have coincided in some countries in the 1980s, it is now clear that the impact of the latter was largely independent of the former, and that countries which rejected multiculturalism fared no better in defending the welfare state than those countries that embraced multiculturalism. Whatever the relationship between multiculturalism and solidarity, it is not a simple hydraulic one, in which one goes down when the other goes up.

But this isn't to say that there aren't more specific contexts or dimensions where they might conflict. Moreover, the findings to date do not provide much guidance for predicting what would happen if, as many progressives desire, we attempted to strengthen either multiculturalism or redistribution beyond what currently exists. It would help if we could move beyond bare regression models to uncover some of the actual mechanisms that underpin (or erode) inclusive solidarity.

As a start, I'd like to return to the rise of neoliberalism in the 1980s, which is widely seen as a paradigmatic example of the decline in solidarity. Was there a significant decline in solidarity at this time, and if so, what caused it? I've already mentioned that it is implausible to blame multiculturalism - the depth of neoliberal reforms was not connected to the presence or absence of multiculturalism policies - but what then did cause the decline in solidarity?

One perhaps surprising answer is that there may not in fact have been any significant change in feelings of solidarity, as least as measured by support for general principles of the welfare state. Several studies have shown a remarkable stability in attitudes to the role of the state in reducing inequalities and ensuring equal opportunities before, during, and after the heyday of neoliberalism in the 1980s and 1990s. ${ }^{18}$ This period witnessed significant changes in the strategic balance of power held by various actors, but not it seems in underlying public attitudes.

If we dig a bit deeper, however, it turns out that there have been more subtle changes in attitudes of solidarity. Cavaillé and Trump (2015) argue that, at least in the British case, while there has been little change in public support for the general principle that the state should reduce inequality (what they call "redistribution from"), there has been a hardening of attitudes towards specific recipients (what they call "redistribution to"), including the unemployed, single mothers and immigrants. Put more colloquially, it 
seems that the public continues to think that the rich don't deserve their good fortune, and so should be taxed, but have started to believe that perhaps the disadvantaged do deserve their bad fortune, and so are less keen to support them. ${ }^{19}$

What explains this hardening of attitudes to the recipients of welfare? Commentators typically refer to "deservingness" judgements, which include judgements about the extent to which someone's misfortune or disadvantage was under their voluntary control. But the evidence suggests that deservingness judgements also track three other criteria: "identity" (the extent to which recipients are seen as belonging to a shared society), "attitude" (the extent to which recipients are seen as accepting benefits in the spirit of civic friendship); and "reciprocity" (the extent to which recipients are seen as likely to help others when it is their turn to do so). ${ }^{20}$

The relevance of these criteria should not be surprising if, as I argued earlier, the welfare state is not primarily about either class struggle or universal humanitarianism, but rather about an ethic of social membership. Judgements of identity, attitude and reciprocity are all different dimensions of the idea that the welfare state embodies Marshall's "direct sense of community membership".

It is also perhaps not surprising that these criteria work to the detriment of immigrants. While several recipient groups are burdened by deservingness judgements, immigrants in Europe invariably come out at the bottom of the ranking of deservingness. Van Oorschot indeed calls this "a truly universal element in the popular welfare culture of present Western welfare states” (Van Oorschot, 2006: 25). ${ }^{21}$ This is arguably a key factor in explaining the rise of welfare chauvinism, at the expense of a more inclusive solidarity. ${ }^{22}$

If this is indeed part of the explanation for the failure of inclusive solidarity, then the urgent question is how we can counteract these trends? One option, in line with power resource theory, is to hope that immigrants over time will gain enough voting clout to muscle their way into the welfare state, even in the face of negative deservingness judgements. ${ }^{23}$ Another option, in line with post-national cosmopolitanism in political theory, is to hope that citizens can be persuaded to separate their views of the welfare state from ideas of community membership, and to instead appeal to universal humanitarianism. ${ }^{24}$

Both of these options seek to extend protection to immigrants without relying on national solidarity. But as I've indicated, I believe that national solidarity will continue to play an important role in shaping the welfare state for the foreseeable future, and we need therefore to think seriously about how immigrants can be part of an inclusive national solidarity.

To make progress on this question, we need to better understand why immigrants are at the bottom of the deservingness ladder. In the literature on anti-immigrant attitudes, two broad explanations are offered: one rooted in perceptions of economic threat or economic burden (e.g., immigrants as free riders), and the other in perceptions of cultural threat (immigrants as irremediably other). How we build inclusive solidarity will depend, at least in part, on the weight we assign to these two dynamics.

Insofar as immigrants are seen as disproportionately reliant on social assistance, and therefore as free-riders, then the relevant responses might be to redesign the welfare state to make it more universalist. We know that deservingness judgements are "primed" when the welfare state is organized on a more selective basis, using means-tested benefits, 
which makes recipients more visible, and invites - indeed almost requires - debates about their deservingness. Various scholars have shown that this dynamic, and its pernicious effects on immigrants, is diminished in more universalistic welfare states (Van der Waal, De Koster \& Van Oorschot, 2013; Larsen, 2006; Swank \& Betz, 2003; Van Oorschot, 2000; Kumlin \& Rothstein 2010; Rothstein 2015).

We might go further and argue that social policy needs to be reorganized to focus more on "predistribution" rather than "redistribution" (Hacker, 2011) - that is, changing how markets distribute rewards in the first place. This includes policies such as higher minimum wages, laws to facilitate union organizing and collective bargaining, or strengthened labour activation policies. ${ }^{25}$ It could also include more radical proposals for "stakeholder grants" (Ackerman \& Alstott, 1999) and "property-owning democracy" (Rawls, 1971), aimed at giving everyone a "fair stake" in society, and equalizing the assets that people bring to the market. ${ }^{26}$ Relying exclusively on post-hoc redistribution creates a double jeopardy: the rich are inclined to believe they have 'earned' their income, and to doubt the deservingness of welfare recipients. As Hacker notes, progressive reformers need to focus on market reforms that encourage a more equal distribution of economic power and rewards even before government collects taxes or pays out benefits. This is not just because pre-distribution is where the action is. It is also because excessive reliance on redistribution fosters backlash, making taxes more salient and feeding into the conservative critique that government simply meddles with "natural" market rewards (Hacker, 2011)

I'm sympathetic to such proposals, which surely would reduce the scope for negative deservingness judgements regarding immigrants, and which in any event are intrinsically desirable from a liberal egalitarian perspective. However, I do not believe that these reforms are a full answer to the challenge of inclusive solidarity. One obvious problem is sequencing. Once it's up and running, a stakeholder society that prioritizes predistribution over redistribution may minimize perceptions of free-riding and economic burden, but how do we get from here to there?

Moreover, I do not believe that perceptions of economic burden are the primary obstacle to inclusive solidarity. Several studies of the sources of anti-immigrant attitudes find that while immigrants are seen as both economic and cultural threats, the cultural threat is the more powerful factor. For example, most people would rather have fewer immigrants who are a net drain on the welfare state than have large numbers of immigrants who are net contributors to the welfare state (Sniderman \& Hagendoorn, 2007; Sides \& Citrin, 2007). This is confirmed by Edward Koning's comparative analysis of welfare chauvinism, which shows that the desire to withhold benefits from immigrants is not correlated with actual levels of welfare dependence. Even low levels of welfare dependence can be mobilized to justify welfare chauvinism if politicians present the recipients as a cultural threat, while quite high levels of welfare dependence may not trigger welfare chauvinism if politicians do not frame this as an issue of cultural threat (Koning, 2013). In short, the perception of economic burden is an effect of perceptions of cultural otherness, not vice versa.

If true, this suggests that redesigning the welfare state to minimize opportunities for deservingness judgements is not sufficient. We need to directly tackle perceptions of cultural "otherness", and to support perceptions of shared membership. But how should we do this? Here we see a clear fork in the road, with a choice between coercive civic integration and liberal multiculturalism. 
In a peculiar and perhaps perverse way, some of the coercive and paternalistic "civic integration" policies spreading throughout Europe can be seen as a response to this challenge. ${ }^{27}$ While part of the impetus for these policies is simple xenophobia, other defenders of these policies may sincerely believe that they can help overcome deservingness judgements to achieve inclusive solidarity. If immigrants are forced to learn the national language and to take integration classes and perform public service in return for welfare, this may counteract the image of not belonging and not reciprocating. If immigrants are seen as not complying with an ethic of social membership, well then let's force them to comply!

I have elsewhere argued that such policies - when mandatory - involve a level of coercion and paternalism that is illiberal, and so normatively illegitimate (Kymlicka, 2012). ${ }^{28}$ But for our purposes, a deeper problem is that this approach is self-defeating. When the state claims that these polices must be mandatory in order to be effective, then it in fact confirms public suspicions that immigrants, left to their own devices, are by inclination uninterested in belonging, and unwilling to contribute and reciprocate. To counteract deservingness judgements, we need instead to create opportunities for immigrants to voluntarily indicate their sense of belonging, civic friendship and reciprocity.

Moreover, these civic integration policies arguably bring nationhood into the story in the wrong way. Nationhood works best when it is deep in the background, as a takenfor-granted presupposition of social life, such that it can indeed be "invisible". The invisibility of nationhood may be a methodological sin in social science, but it is arguably a social virtue. For when nationhood is highlighted or primed - when it is taken from the back of people's minds to the front of their minds - there is evidence that it triggers xenophobia. This is one of the results of what are called "mere mention" experiments. In these experiments, one group of respondents is asked "do you believe immigrants deserve this or that right". Another group of people are asked the same question, but with a national prime: they are asked: "You are Dutch: do you believe immigrants deserve X". The "mere mention" of nationhood produces systematically harsher answers. ${ }^{29}$ Coercive civic integration policies are, in effect, repeated iterations of these mere mention tests: repeatedly poking and prodding immigrants, asking "are you Dutch yet?". This perhaps explains why the evidence to date suggests that civic integration policies are not overcoming exclusionary forms of solidarity (Goodman \& Wright 2015; Gundelach \& Traunmüller, 2014).

What is the alternative? I would suggest that we need to develop a form of multiculturalism that is tied to an ethic of social membership: that is, a form of multiculturalism that enables immigrants to express their culture and identity as modes of participating and contributing to the national society. A solidarity-promoting multiculturalism would start from the premise that one way to be a proud and loyal Canadian is to be a proud Greek-Canadian or Vietnamese-Canadian, and that the activities of one's group - be they religious, cultural, recreational, economic or political - are understood as forms of belonging, and of investing in society, not only or primarily in the economic sense, but in a deeper social sense, even (dare I say it?) as a form of nation-building.

Indeed if there is one thing to be said on behalf of Canadian multiculturalism, it is precisely this: multiculturalism in Canada has always been seen, by both immigrants 
and native-born citizens, as a means of contributing to society, and indeed a form of nation-building. ${ }^{30}$ It is a means of staking a claim to social membership, in part by seeking the accommodations needed to participate more fully and effectively, but also of fulfilling the responsibilities of social membership. I do not think this is unique to Canada: I see the same link between multiculturalism and national contribution in Australia (Levey, 2008, 2016) or Scotland (Hussain \& Miller 2006).

This, I think, is the most promising avenue for inclusive solidarity - a multicultural liberal nationalism, if you will. I believe it is more promising than relying on the vagaries of power politics or an appeal to universal humanitarianism or on coercive civic integration. I emphasize, however, once again, that this is highly speculative. We do not have the sort of evidence needed to confirm the reciprocal impacts of multiculturalism, national solidarity, and the welfare state. And even if the evidence existed, it would just push the question back. If multicultural nationhood is the precondition of inclusive solidarity, what are the preconditions of multicultural nationhood? ${ }^{31}$

And here, as a last word, let me enter a word of caution, particularly in light of the theme of this conference. I believe that multicultural nationhood is both a normatively attractive ideal, and a potential source of inclusive solidarity, and that we have at least some partial instantiations of this ideal in the real world. But the cases I've mentioned - Canada, Australia and Scotland - share an important feature. They are societies whose immigrants have traditionally been seen as permanent residents and future citizens. Or at any rate, their policies of multicultural nationalism are built on this assumption. And this assumption is partly what makes the model of multiculturalism-asnational-contribution powerful and plausible: permanent residents and future citizens have a clear self-interest in investing in society, becoming members, and contributing to it. It is far less clear that this model of multiculturalism works for temporary migrants, and indeed both Canada and Australia have recently been struggling with the question or whether or how their multiculturalism policies apply to temporary migrants.

Some people believe that the very distinction between permanent and temporary migration is breaking down, and that we will soon be living in a world of "superdiversity" with a multitude of legal statuses that are neither wholly temporary nor wholly permanent, but rather have varying degrees and levels of conditionality and precariousness (Vertovec, 2007, 2016). I am far from sure that such a world is desirable. I am even less sure what would be the source of solidarity in such a world of liquid mobility.

\section{Endnotes}

${ }^{1}$ There are now hundreds of studies done on this topic. For recent meta-analyses of these studies, documenting their inconclusive results, see Van der Meer and Tolsma, (2014); Stichnoth and Van der Straeten, (2013); Schaeffer, (2014). As Stolle and Harell, (2015) note, this literature seems to have reached a "stalemate".

${ }^{2}$ For influential accounts, see Moore (2001), Miller (1995), Tamir (1993), Gans (2003), McCormick (1999), Canovan (1996).

${ }^{3}$ Rawls (1993) famously argued that political theorists need to treat these facts of pluralism as a permanent feature of any free society. Unfortunately, like most other contemporary political theorists, he does not apply his own logic to the question of 
units of governance, and assumes instead that preferences on that question will be unified.

${ }^{4}$ And conversely, the relatively few cases in the West where boundaries are unstable are cases of competing nation-building, as in Northern Ireland, Belgium and Cyprus. If nationhood offers the clearest route to generate converging preferences on units, so too competing nationhood offers the clearest route to disrupt that convergence, generating the need for models of multination states that seek to ensure fairness amongst the competing national groups in their ability to enact their national identities (through language rights and self-government powers etc.).

${ }^{5}$ For a related point, see Bauman's discussion of the need to look beyond momentary "carnivals of solidarity" to see whether and how solidarity operates in the "the silence of the dispassionate routine" of institutionalized social life (Bauman, 2013).

${ }^{6}$ As Laitinen and Pessi put it, not all pro-social feelings qualify as solidarity: "as solidarity is often based on we-thinking, it can be separated not only from anti-social egocentrism, but also from one-sided 'thou-centrism', such as altruism, sympathy, caring, or Christian charity. While these concentrate on the wellbeing of the other or you, the target of concern in solidarity can be us together" (Laitinen \& Pessi, 2014: 2).

${ }^{7}$ Some cosmopolitan theorists have raised philosophical objections to this picture of bounded solidarity, and argue that we should think of ourselves as equally obligated to all humans, close or distant, insiders or outsiders. I will not enter into that philosophical debate here, except to note that (a) all existing welfare states do rely on bounded solidarity; and (b) we should not assume that renouncing appeal to bounded solidarities and removing the distinction between insiders and outsiders will lead to levelling up the treatment of outsiders. It might instead lead to levelling down of the treatment of insiders. It may be that bounded solidarity was (and continues to be) needed to motivate people to accept obligations beyond duties of rescue and humanitarian need.

${ }^{8}$ See historian Ben Jackson's observation that historically successful appeals for egalitarian politicians in the USA and the UK tended to be expressed in the idiom of national solidarity, and that "redistribution expressed the fairness and solidarity of the national character" (Jackson, 2009: 239).

${ }^{9}$ There is considerable variation across time and space in the extent to which a strong welfare state is seen as necessary to instantiate this ethic of social membership compare the US and Sweden. But while the ethic of social membership implicit in nationhood is not inherently linked to pro-redistributive views, it is inherently egalitarian in its conception of social status, or at least anti-elitist. In earlier periods of European history, elites tried to dissociate themselves from 'the plebs' or 'the rabble', and justified their powers and privileges precisely in terms of their alleged distance from the masses. The lords were seen, not only as a different class, but as a different and superior race of people, with their own language and civilization, unrelated to the folk culture of the peasants in their midst, and this was the basis of their right to rule. The rise of nationalism, by contrast, valorized 'the people'. Nations are defined in terms of 'the people' - ie. the mass of population on a territory, regardless of class or occupation who become "the bearer of sovereignty, the central object of loyalty, and the basis of collective solidarity" (Greenfeld, 1992: 14). The "arrival of nationalism" therefore "was tied to the political baptism of the lower classes" (Nairn, 1977: 41). The use of the 
vernacular in modern political life is a manifestation of this shift, confirmation that the political community really does belong to the people, and not to the elite. And while national communities still exhibit major economic inequalities, the different economic classes are no longer seen as separate races or cultures. It is seen as right and proper that lower-class children are exposed to the high culture of literature and the arts (which itself has become expressed in the vernacular), while upper-class children are exposed to the history and folk culture of the people. All individuals within the territory are supposed to share in a common national culture, speak the same national language, and participate in common educational and political institutions. In short, nationalism created the myth of a single national community which encompasses all classes on the territory. And within the Western democracies, substantial progress was made towards realizing this myth, as the achievement of a wider franchise, mass literacy and the welfare state enabled almost all citizens to participate, however unequally, in common national cultural and political institutions operating in the vernacular. This vision is under strain, given recent trends towards rising inequality, but national identity has remained strong in the modern era in part because its emphasis on the importance of 'the people' provides a source of dignity to all individuals, against all the other social forces that work to separate elites from the masses. We can see the Occupy movement as an attempt to reassert this image in the face of growing inequality and the societal divorce of the $1 \%$ from the masses. As discussed below, it is not clear that 'postnational' approaches have any comparable capacity to bind elites to the masses.

${ }^{10}$ This is a central theme in Brooks and Manza (2007), who argue that welfare state regimes endure, despite declining working class power, in part because they have become embedded in public discourse and collective memories, albeit to different degrees in different countries.

${ }^{11}$ Since this IMISCOE conference is on mobility, I will focus on immigrant-origin multiculturalism, rather than the claims of indigenous peoples or substate nations. Insofar as the latter raise issues about territorial boundaries and self-determination claims, they not only challenge the role of nationhood in generating solidarity, but even its ability to stabilize boundaries (Kymlicka, 2001).

${ }^{12}$ All these organizations eventually retreated from more extreme forms of 'market fundamentalism, and some commentators argue that we can therefore distinguish a "neoliberal era" (say, 1980 to 1995) from a "post-neoliberal era" (say, 1995 to the economic crisis of 2008), which did not reverse neoliberal market reforms, but which qualified and supplemented them with social investment policies. For an excellent history of neoliberalism, and its uneven rise and fall, see Evans and Sewell (2013).

${ }^{13}$ This trajectory is not unique to multiculturalism: for example, we can see similar transformations from emancipatory to neoliberal versions of gay rights. And in both cases, the trajectory is contested, and the struggle between the two versions remains ongoing.

${ }^{14}$ Sainsbury, (2012); Koning, (2013); Reeskens and Van Oorschot (2012). In these cases, "a strong defense of social solidarity - a strong internal 'community of fate' - seems to have come bundled with strict boundaries to the outside" (Thelen, (2014): 200).

${ }^{15}$ Logically, a fourth option is neoliberal assimilation. As noted earlier, that indeed was the initial position of Thatcher and Reagan, and it seems to be returning in some parts of the right in the US and UK, and perhaps elsewhere. From a philosophical 
perspective, neoliberal assimilation involves a puzzling mix of economic liberalism and cultural conservatism.

${ }^{16}$ And Collier himself provides no evidence that multiculturalism policies erode solidarity.

${ }^{17}$ For similar observations about how solidarity has been dismissed by academics as "rhetorical" or "ceremonial", see Reynolds, (2014): 1; Laitinen and Pessi (2014): 1.

${ }^{18}$ For arguments about the stability of attitudes of solidarity, see Brooks and Manza (2007); Cavaillé and Trump (2015).

${ }^{19}$ See also McCall (2013) on public opinion regarding "the undeserving rich".

${ }^{20}$ For a review of these findings, see Van Oorschot (2006).

${ }^{21}$ According to Van Oorschot, we should expect immigrants to be seen as undeserving because "one can assume that migrants will tend to 'score' less positively, or more negatively, on all criteria usually apply when assessing a person's or a group's deservingness" (Van Oorschot 2005: 6).

${ }^{22}$ As Van Oorschot notes, deservingness judgements are essentially the flip side of feelings of solidarity: "In fact, one could argue that the difference between both concepts is more a matter of disciplinary origin and context, with 'solidarity' having a tradition in sociology, and 'deservingness' having its roots in social psychology" (Van Oorschot 2005: 10n3).

${ }^{23}$ That voting clout does indeed matter has been documented by Koopmans, Michalowski and Strinnbe, (2012).

${ }^{24}$ See, for example, Kochenov, (2015).

25 "Prepare not repair", as the slogan goes (Morel, Palier \& Palme, 2011).

${ }^{26}$ For a helpful review of these models of egalitarian capitalism, see Ackerman, Alstott and Van Parijs (2006) and O'Neill and Williamson (2012)

${ }^{27}$ For overviews of this trend, see Joppke (2007); Goodman (2010, 2014).

${ }^{28}$ As Triadafilopoulos (2011) puts it, these policies manifest a "Schmittian liberalism".

${ }^{29}$ Interestingly, this effect is not found in Canada (Breton, 2015).

${ }^{30}$ This analysis is shared by both defenders of Canadian multiculturalism, such as myself and Varun Uberoi, (2008), and critics, such as Gerald Kernerman (2005) or Richard Day (2000). They view the fusing of multiculturalism with nation-building as an abandonment of its emancipatory potential. I view it as enabling an ethos of social membership that affirms both diversity and solidarity.

${ }^{31}$ For some speculations, see Kymlicka, (2007).

\section{Acknowledgements}

An earlier version of this paper was presented at the IMISCOE "Mobility in Crisis" conference at the European University Institute in January 2015. Thanks to Rainer Bauböck, Peter Scholten, Willem Maas and Claus Offe for their challenging commentaries at the conference, and to Sue Donaldson and Keith Banting for their suggestions. The paper draws on work being conducted in collaboration with Keith as part of our project on "The Strains of Commitment: The Political Sources of Solidarity in Diverse Societies". 
Ackerman, B. Alstott, A. \& Van Parijs, P. (2006). Redesigning Distribution: Basic Income and Stakeholder Grants as Cornerstones for an Egalitarian Capitalism. London: Verso.

Alexander, J. (2014). "Morality as a Cultural System: On Solidarity Civil and Uncivil". In V. Jeffries (Ed.), Palgrave Handbook of Altruism, Morality and Social Solidarity (pp. 303-10). London: Palgrave.

Banting, K. \& Kymlicka, W. (2006). Multiculturalism and the Welfare State: Recognition and Redistribution in Contemporary Democracies. Oxford: Oxford University Press.

Banting, K. \& Kymlicka W. (in press). "Introduction: The Political Sources of Solidarity in Diverse Societies". In Banting, K. $\&$ Kymlicka, W. (Eds). The Strains of Commitment: The Political Sources of Solidarity in Diverse Societies.

Bauman, Z. (2013). "A Word in Search of Flesh: Solidarity". New Eastern Europe, 2(VII), 1-6.

Bayertz, K. (1998). "Solidarity and the welfare state: Some introductory considerations". Ethical Theory and Moral Practice, 1, $293-296$.

Benhabib, S. (2006). Another cosmopolitanism. Oxford: Oxford University Press.

Berman, S. (2006). The Primacy of Politics: Social Democracy and the Making of Europe's Twentieth Century. Cambridge: Cambridge University Press.

Brady, D. \& Finnigan, R. (2014). "Does Immigration Undermine Public Support for Social Policy". American Sociological Review, 79(1), 17-42

Breton, C. (2015). "Making National Identity Salient: Impact on Attitudes toward Immigration and Multiculturalism". Canadian Journal of Political Science. doi:10.1017/S0008423915000268

Brooks, C. \& Manza, J. (2007). Why Welfare States Persist: The Importance of Public Opinion in Democracies. Chicago: University of Chicago Press.

Calhoun, C. (2002). "Imagining Solidarity: Cosmopolitanism, Constitutional Patriotism, and the Public Sphere". Public Culture, 14(1), 147-71.

Canovan, M. (1996). Nationhood and Political Theory. Cheltenham: Edward Elgar.

Cardinal, L. \& Denault, A.-A. (2007). "Empowering Linguistic Minorities: Neo-liberal Governance and Language Policies in Canada and Wales". Regional \& Federal Studies, 17(4), 437-56.

Cavaillé, C. \& Trump, K.-S. (2015). "The Two Facets of Social Policy Preferences". Journal of Politics, 77(1), 146-60.

Collier, P. (2013). Exodus: How Migration is Changing Our World. Oxford: Oxford University Press.

Connolly, W. (2000). "The Liberal Image of the Nation". In D. Ivison, P. Patton, \& W. Sanders (Eds.), Political Theory and the Rights of Indigenous Peoples (pp. 183-98). Cambridge: Cambridge University Press.

Crepaz, M. (2006). "If you are my brother, I may give you a dime!". Public Opinion on Multiculturalism, Trust and the Welfare State". In K. Banting \& W. Kymlicka (Eds.), Multiculturalism and the Welfare State (pp. 92-118). Oxford: Oxford University Press.

Day, R. J. F. (2000). Multiculturalism and the History of Canadian Diversity. Toronto: University of Toronto Press.

Esping-Andersen, G. (1985). Politics Against Markets: The Social Democratic Road to Power. Princeton: Princeton University Press.

Esping-Andersen, G. (1990). The Three Worlds of Welfare Capitalism. Princeton: Princeton University Press.

Evans, P. \& Sewell, W. (2013). "Neoliberalism: Policy Regimes, International Regimes, and Social Effects". In P. A. Hall \& M. Lamont (Eds.), Social Resilience in the Neoliberal Era (pp. 35-68). Cambridge: Cambridge University Press.

Gans, C. (2003). The Limits of Nationalism. Cambridge: Cambridge University Press.

Goodman, S. (2010). "Integration Requirements for Integration's Sake? Identifying, Categorizing and Comparing Civic Integration Policies". Journal of Ethnic and Migration Studies, 36(5), 753-72.

Goodman, S. (2014). Immigration and Membership Politics in Western Europe. Cambridge: Cambridge University Press.

Goodman, S. \& Wright, M. (2015). "Does Mandatory Integration Matter? Effects of Civic Requirements on Immigrant Socioeconomic and Political Outcomes". Journal of Ethnic and Migration Studies, 41(12), 1885-1908.

Greenfeld, L. (1992). Nationalism: Five Roads to Modernity. Cambridge: Harvard University Press.

Guimond, S. Crisp, R. J., De Oliveira, P., Kamiejski, R., Kteily, N., Kuepper, B., et al. (2013). "Diversity Policy, Social Dominance, and Intergroup Relations: Predicting Prejudice in Changing Social and Political Contexts". Journal of Personality and Social Psychology, 104(6), 941-58.

Gundelach, B. \& Traunmüller, R. (2014). "Norms of Reciprocity as an Alternative Form of Social Capital in an Assimilationist Integration Regime". Political Studies, 62, 596-617.

Habermas, J. (2000). "The Postnational Constellation and the Future of Democracy". In Postnational Constellation: Political Essays. Cambridge, Mass: MIT Press.

Hacker, J.S. (2011). The institutional foundations of middle-class democracy. Policy Network. Retrieved from http://www. policy-network.net/pno_detail.aspx?ID=3998\&title=The+institutional+foundations+of+middle-class+democracy

Hale, C. R. (2005). "Neoliberal Multiculturalism: The Remaking of Cultural Rights and Racial Dominance in Central America". PoLAR: Political and Legal Anthropology Review, 28(1), 10-28.

Hussain, A. \& Miller, W. L. (2006). Multicultural Nationalism: Islamophobia, Anglophobia, and Devolution. Oxford: Oxford University Press.

Jackson, B. (2009). "The rhetoric of redistribution". In J. Callaghan, N. Fishman, B. Jackson, \& M. Mclvor (Eds.), In Search of Social Democracy. London: Palgrave.

Joppke, C. (2007). "Immigrants and Civic Integration in Western Europe". In K. Banting, T. Courchene, \& L. Seidle (Eds.), Belonging? Diversity, Recognition and Shared Citizenship in Canada. Montreal: Institute for Research on Public Policy.

Kernerman, G. (2005). Multicultural nationalism: civilizing difference, constituting community. Vancouver: UBC Press.

Kesler, C. \& Bloemraad, I. (2010). "Does Immigration Erode Social Capital? The Conditional Effects of ImmigrationGenerated Diversity on Trust, Membership, and Participation across 19 Countries, 1981-2000". Canadian Journal of Political Science, 43(2), 319-47.

Kochenov, D. (2015). "Growing apart Together: Social Solidarity and Citizenship in Europe". In F. Pennings \& G. Vonk (Eds.), Research Handbook on European Social Security Law. Cheltenham: Edward Elgar.

Koning, E. A. (2013). "Selective Solidarity: The politics of immigrants' social rights in Western welfare states," (Doctoral dissertation). Kingston, Ontario, Canada: Retrieved from Queen's University. https://qspace.library.queensu.ca/ bitstream/1974/7922/1/Koning_Edward_A_201304_PhD.pdf. 
Koopmans, R., Michalowski, I. \& Strinnbe, W. (2012). "Citizenship Rights for Immigrants: National Political Processes and Cross-National Convergence in Western Europe: 1980-2008". American Journal of Sociology, 117(4), 1202-45.

Korpi, W. (1983). The Democratic Class Struggle. London: Routledge.

Kumlin, S. \& Rothstein, B. (2010). "Questioning the New Liberal Dilemma: Immigrants, Social Networks and Institutional Fairness". Comparative Politics, 43(5), 63-80.

Kymlicka, W. (2001). Politics in the Vernacular: Nationalism, Multiculturalism, Citizenship. Oxford: Oxford University Press. Kymlicka, W. (2007). Multicultural Odysseys. Oxford: Oxford University Press.

Kymlicka, W. (2012). "Multiculturalism: Success, Failure, and the Future". Washington, DC: Migration Policy Institute. http:// www.migrationpolicy.org/research/TCM-multiculturalism-success-failure.

Kymlicka, W. (2013). "Neoliberal Multiculturalism?". In P. Hall \& M. Lamont (Eds.), Social Resilience in the Neoliberal Era (pp. 99-125). Cambridge: Cambridge University Press.

Laitinen, A. \& Pessi, A. B. (2014). "Solidarity: Theory and Practice. An Introduction". In A. Laitenen \& A. Pessi (Eds.), Solidarity: Theory and Practice. Lanham: Lexington Books.

Larsen, C. A. (2006). The Institutional Logic of Welfare Attitudes: How Welfare Regimes Influence Public Support. Hampshire: Ashgate.

Levey, G. B. (2008). Political Theory and Australian Multiculturalism. New York: Berghahn.

Levey, G. B. (2016). "Diversity, Duality and Time". In N. Meer, T. Modood, \& R. Zapata-Barrero (Eds.), Multiculturalism and Interculturalism: Debating the Dividing Lines. Edinburgh: Edinburgh University Press.

Marshall, T. H. (1963). Sociology at the Crossroads. London: Heinemann.

McCall, L. (2013). The Undeserving Rich: American Beliefs about Inequality, Opportunity, and Redistribution. Cambridge: Cambridge University Press.

McCormick, N. (1999). "Nations and Nationalism". In R. Beiner (Ed). Theorizing Nationalism Albany: SUNY Press.

Menz, G. (2013). "European Employers and the Rediscovery of Labour Migration". In E. Jurado \& G. Brochmann (Eds.), Europe's Immigration Challenge: Reconciling Work, Welfare and Mobility (pp. 105-123). London: I.B. Tauris.

Miller, D. (1995). On Nationality. Oxford: Oxford University Press.

Mitchell, K. (2004). Crossing the Neoliberal Line: Pacific Rim Migration and the Metropolis. Philadelphia: Temple University Press.

Moore, M. (2001). The Ethics of Nationalism. Oxford: Oxford University Press.

Morel, N., Palier, B. \& Palme, J. (2011). "Beyond the Welfare State as We Knew It?". In N. Morel, B. Palier, \& J. Palme (Eds.), Towards a Social Investment Welfare State. Bristol: Policy Press.

Nairn, T. (1977). The Break-Up of Britain: Crisis and Neo-Nationalism. London: New Left Books.

O'Neill, M. \& Williamson, T. (2012). Property-Owning Democracy: Rawls and Beyond. Wiley-Blackwell

Rawls, J. (1971). A Theory of Justice. London: Oxford University Press.

Rawls, J. (1993). Political Liberalism. New York: Columbia University Press.

Reeskens, T. \& Van Oorschot, W. (2012). "Disentangling the 'New Liberal Dilemma': On the relation between general welfare redistribution preferences and welfare chauvinism". International Journal of Comparative Sociology, 53(2), $120-39$.

Reynolds, P. (2014). "Introduction". In S. Boyd \& W. Mary Ann (Eds.), Cultural Difference and Social Solidarity: Solidarities and Social Function. Newcastle: Cambridge Scholars Publishing.

Rothstein, B. (2015). "Solidarity, Diversity and the Quality of Government". In K. Banting \& W. Kymlicka (Eds.), The Strains of Commitment: The Political Sources of Solidarity in Diverse Societies. Oxford: Oxford University Press, forthcoming.

Sager, A. (2014). "Methodological Nationalism, Migration and Political Theory". Political Studies. Wiley Online Library. doi: $10.1111 / 1467-9248.12167$

Sainsbury, D. (2012). Welfare states and immigrant rights: the politics of inclusion and exclusion. Oxford: Oxford University Press.

Schaeffer, M. (2014). Ethnic Diversity and Social Cohesion: Immigration, Ethnic Fractionalization and Potentials for Civic Action. Farnham: Ashgate.

Scholz, S. J. (2008). Political Solidarity. University Park: Penn State University Press.

Sides, J. \& Citrin, J. (2007). "European opinion about immigration: The role of identities, interests and information". British Journal of Political Science, 37(3), 477-504.

Sniderman, P. \& Hagendoorn, L. (2007). When Ways of Life Collide: Multiculturalism and Its Discontents in the Netherlands. Princeton: Princeton University Press.

Stephens, J. (1979). The Transition from Capitalism to Socialism. London: Macmillan.

Stichnoth, H. \& Van der Straeten, K. (2013). "Ethnic Diversity, Public Spending, and Individual Support for the Welfare State: A Review of the Empirical Literature". Journal of Economic Surveys, 27(2), 364-89.

Stjernø, S. (2004). Solidarity in Europe: The History of an Idea. Cambridge: Cambridge University Press.

Stolle, D. \& Harell, A. (2015). "The Consequences of Ethnic Diversity: Advancing the Debate". In R. Koopmans, B. Lancee, \& M. Schaeffer (Eds.), Social Cohesion and Immigration in Europe and North America: Mechanisms, Conditions, and Causality. London: Routledge.

Swank, D. \& Betz, H-G. (2003). "Globalization, the welfare state and right-wing populism in Western Europe". SocioEconomic Review, 1(2), 215-245.

Tamir, Y. (1993). Liberal Nationalism. Princeton: Princeton University Press.

Thelen, K. (2014). Varieties of Liberalization and the New Politics of Social Solidarity. Cambridge: Cambridge University Press.

Triadafilopoulos, P. (2011). "Illiberal Means to Liberal Ends? Understanding Recent Immigrant Integration Policies in Europe". Journal of Ethnic and Migration Studies, 37(6), 861-80.

Uberoi, V. (2008). "Do Policies of Multiculturalism Change National Identities?". Political Quarterly, 79, 404-17.

Van der Meer, T. \& Tolsma, J. (2014). "Ethnic diversity and its supposed detrimental effects on social cohesion". Annual Review of Sociology, 40, 459-78.

Van der Waal, J., De Koster, W. \& Van Oorschot, W. (2013). “Three Worlds of Welfare Chauvinism? How Welfare Regimes Affect Support for Distributing Welfare to Immigrants in Europe". Journal of Comparative Policy Analysis, 15(2), 164-81. 
Van Oorschot, W. (2000). "Who should get what, and why". Policy and Politics, 28(1), 33-49.

Van Oorschot, W. (2005). "Immigrants, Welfare and Deservingness: Opinions in European Welfare States". Aalborg University: Institut for Okonomi, Politik og Forvaltning.

Van Oorschot, W. (2006). "Making the difference in social Europe: deservingness perceptions among citizens of European welfare states". Journal of European Social Policy, 16(1), 23-42.

Vertovec, S. (2007). 'Super-diversity and its implications'. Ethnic and Racial Studies, 29(6), 1024-54.

Vertovec, S. (2016). Super-diversity. London: Routledge.

Wilde, L. (2007). "The Concept of Solidarity: Emerging from the Theoretical Shadows". British Journal of Politics and International Relations, 9(1), 171-81.

Žižek, S. (1997). "Multiculturalism, or the Cultural Logic of Multinational Capitalism". New Left Review, 225, 28-51.

Submit your manuscript to a SpringerOpen ${ }^{\circ}$ journal and benefit from:

- Convenient online submission

- Rigorous peer review

- Immediate publication on acceptance

- Open access: articles freely available online

- High visibility within the field

- Retaining the copyright to your article

Submit your next manuscript at $>$ springeropen.com 